\title{
Development of Cooperative Learning Strategy On Mathematics Subject for Students with Learning Disabilities in Primary Schools
}

\author{
Imas Diana Apriliaa ${ }^{\text {a }}$ Yanti Sam Amir ${ }^{\text {b }}$, Tjutju Soendari ${ }^{\mathrm{c}}$ \\ ${ }^{a b c}$ Special Education Departemen, Faculty of Science Education \\ Universitas Pendidikan Indonesia \\ Bandung, Indonesia
}

Corresponding e-mail: imasdiana@upi.edu

\begin{abstract}
The diversity of students' abilities in primary schools, especially in the mastery of mathematics subject, is often ignored by teachers. Inaccuracy of teachers to analyze the needs of students makes learning in mathematics subject tend to be classical and less accomodate diversity of potential students themselves, less optimal development of self-ability and social skills, including in the classroom in which there are students with learning disfficulties. This study aims to formulate cooperative learning strategies in mathematics subject for students with learning disabilities in primary schools. The research method used descriptive qualitative approach. The research was divided into three stages: preliminary stages, assessing the objective condition of the students' learning ability and the way of the teacher in learning students with learning disabilities. The second stage, the formulation of cooperative learning strategy. The third stage, test the implementation of cooperative learning strategies. Data collection techniques used observation, interview, documentation studies and mathematical assessment. The results showed that of the three students with learing difficulties in 5th grade, have difficulties in mathematics, especially in the matter of addition. The way of a teacher in teaching the students is not based on the assessment results so that students get the same subject matter. Classroom activity is dominated by teacher through lecture method, classical approach, lack of opportunity for students to discuss and practice mathematics problems. The formulation of cooperative learning strategy produces the components covering rationale, purpose, principle, understanding, material, implementation, and supporting learning. The implementation of the principles of cooperative learning strategies shows that there is consistently and systematic improvement of teacher performance in planning, implementing and evaluating learning in the classroom. The implication is that teachers need to perform numerical assessments, formulate individual programs that accommodate students' diversity, and develop more adaptive and varied learning strategies.
\end{abstract}

Keywords - cooperative learning; learning disabilities; mathematics subject.

\section{INTRODUCTION}

Among children with special needs, there is a group of children called children with learning difficulties, that is those who experience obstacles/difficulties in academic tasks caused by the existence of neurological or central nervous system dysfunction, so that the system does not play properly. The dysfunction of the central nervous system is very influential on the "basic psychological process", namely in the form of inability to hear, think, read, write, converse, and perform mathematical calculations. However, these barriers are non-permanent, but more temporal, so it allows the function to return optimally when educational services are appropriately provided, otherwise the central nervous system dysfunction may aggravate the learning difficulty conditions owned. Their difficulties / obstacles are indicated by the failure of academic achievement in accordance with the expected capacity, which includes the mastery of reading, writing, and / or mathematics / arithmetic skills.

Reading, writing, and numeracy skills are very basic academic skills, meaning they are the foundation to learn other subjects. Cockroft (Abdurahman, M. 2010: 219). Thus, as human beings living in the community, students with learning disabilities need a learning to develop these three skills.

Over the years, the prevalence of students with learning disabilities increase with diverse barriers (Abdurrahman, 2009, Joseph 2003). In Jogjakarta found 36\% children with learning difficulties, that is $12 \%$ of which are slow learner, $16 \%$ specific learning difficulties, and $17 \%$ mentally retarded (Rudiyati, 2010). Masroza (2013) found in every primary school in Padang, ranging from grade I to VI that there are children who have learning difficulties. Among them were $76.6 \%$ had difficulty in reading, $75.3 \%$ had symptoms of slow learning, $66.4 \%$ had under uchiever symptoms (achievement below average), 66.36\% had weaknesses in subjects that were tested in national exam, $61.3 \%$ had difficulty in writing and $48.6 \%$ had difficulty in counting.

The data gives an illustration that the problems of students with learning disabilities related to learning interventions that have not been optimal conducted by teachers (Geary, 2004). Many teachers in regular classes and special classes do not yet understand how to accommodate the instructional needs of students with learning disabilities (Mastropieri \& Scruggs, 1997). While at the same time 
teachers are required to meet the standards of the curriculum set by the government (Gersten \& Chard, 2000).

There are many models, methods, or techniques in the learning that has been used. But so far nothing can really be applied to be able to answer the challenges of learning needs in the classroom in which there are students with learning disabilities. Therefore, it is important to examine how learning can accommodate the diversity of students in the classroom. Learning that can meet the demands of an inclusive classroom is learning that can adapt to the diversity of students needs. The learning has the flexibility to adapt to its design, process and evaluation.

The search for instructional strategies to help teachers improving academic skills students with leraning difficulties is to use cooperative learning strategies (Goor \& Schwen, 1993; Johnson \& Johnson, 1992; Margolis \& Freud, 1991, Murphy \& Rita, 2005). Students will find and understand easily difficult concepts if they can talk about each other in groups (Slavin, 2006, p. 10). Learning in a group that essentially exist in cooperative learning, that is learning in teams or groups with adjustments for students with learning disabilities. Social acceptance of children with special needs by peers can increase interaction between groups (Gilles \& Andrian, 2000, p. 19), help children learn to work together and appreciate cooperation (Antil, Jenkins, Wayne \& Vadasy, 1998).

Cooperative learning can be used in all subjects. A study by Antil, Jenkins, Wayne \& Vadasy (1998) on cooperative learning strategies applied by third-grade teachers that as many as $79 \%$ teachers use cooperative learning in mathematics subjects, and as many as $74 \%$ in language subjects. Another survey of 85 primary school teachers in the United States shows that as many as $93 \%$ teachers use cooperative learning.

Less well-designed group learning will result a situation where learning is dominated by some students, even though in a classroom there are students with learning disabilities who with the possibility of them experiencing barriers to participating in group learning.

To address these weaknesses, it is necessary to develop a group or individual learning strategy that can motivate for each student to learn and help other students.

\section{THEORITICAL REVIEW}

\section{A. Cooperative Learning Strategy}

Cooperative learning strategy based on assumption of cognitive development theory from Piaget and kontruktivisme development theory from Vygotsky. The influence of both theories can underlie the development of learning in an inclusive class by applying the principles or concepts of cooperative learning. Cooperative learning strategy is a learning strategy by using grouping system or small team, between four to six people who have different background of academic ability, gender, race, or ethnic group (heterogen). Assessment system is done to the group. Each group will be awarded (reward), if the group is able to show the required achievement. Thus, each member of the group will have a positive dependence. Then, A positif dependence will lead to individual responsibility for the group and interpersonal skills of each group member. So that every individual will have equal opportunity to contribute for the success of the group. Meanwhile, Sanjaya (2006, p.224) mentions that "Cooperative learning strategy has two main components, namely cooperative task component and cooperative incentive structure. Cooperative tasks relate to what causes members to work together in completing group tasks. Whereas the cooperative incentive structure is considered as the uniqueness of cooperative learning, because through the incentive structure, each member of the group works hard to learn, encourage and motivate other members to master the subject matter, so he/she achieve group goals".

\section{B. Students with Learning Disabilities in Mathematics}

The difficulty of learning in mathematics is a difficulty in using the language symbol to think, record and communicate ideas related to amount and quantity. Mathematical difficulties that a child have is marked with some problems. Teachers need to know the common mistakes made by the child in the completion of tasks in mathematics subject. Based on this, Lerner (in Abdurahman, 2010, p.226) mentions that some common mistakes in mathematics are lack of understanding of (1) symbols, (2) place values, (3) computations, (4) use of the wrong process, and (5) unreadable writing.

\section{III.METHODOLOGY}

This study used a qualitative approach with descriptive method that aims to describe and analyze the results of implementation of cooperative learning strategies for students with learning disabilities through reflection activities. Data collection techniques used interview, observation, documentation studies and mathematics assessment technique. The technique of data validity used data triangulation technique. The subjects of the research were one teacher and three students having difficulty learning in counting in grade 4 .

\section{IV.RESULTS AND DISCUSSION}

\section{A. Objective Condition of Students with Learning Disabilities}

Based on the results of the mathematics assessment, the three students included in the category of frustration level means that they have difficulty in the counting operation of the sum. Based on the analysis that has been done, it can be concluded that the ability of R, D and F is currently still at the basic arithmetic stage, where $\mathrm{R}, \mathrm{D}$ and $\mathrm{F}$ require strengthening and repetition in the basic ability to calculate the symbols, +, -, $\mathrm{x}$, and determine place value. 


\section{B. Learning Objective Conditions}

The result of observation and interview to the teacher about the planning and implementation of learning can be concluded that the school implements the education unit level curriculum in 2006. The school does not make alignment or adaptation of learning for students with learning disabilities in mathematics in grade 4. However the teacher has tried to plan the learning as well as possible in accordance with the syllabus and material contained in the text book. The implementation of mathematics learning for students with learning disabilities is done classically and in group. Group activities are conducted to anticipate the mininm of the text book. Beside that, the teachers implement learning by using learning strategy and methods similar to other students. With this kind of learning, the services of learning needs for students with learning disabilities has not been fully accommodated.

\section{Formulation of Cooperative Learning Strategy Development}

The formulation of cooperative learning strategies for students with learning disabilities can be described as follows:

Table 1. Hypotetic Formulation of Cooperative Learning Strategy Development

\section{Rationale}

Cooperative learning tends to be based on the assumption of cognitive developmental theory of $\mathrm{J}$. Piaget and constructivism theory of Vygotsky. Individual-centered learning and constructing the subjects matter by applying the learning process that builds the social relationships of learners. Learning by Vygotsky takes place within the Proximal Development Zone. This zone explains the level of actual development determined by the problem solving done independently and the level of potential development determined through problem solving under adult guidance or collaborating with peers having more capabilities. While Piaget believes that the limiting factor on things learned by children at any time are the stages of development. In this case Piaget's opinion becomes important to look at the learner's early abilities before designing a learning. This shows the learning process in accordance with the level of development of learners. But Vygotsky's opinion more emphasizes that other people / environments that direct the children to explore their own abilities. Along with the development of children through this Proxsimal Development Zone, the direction given by teachers gradually decreases with the development of learners' knowledge. The influence of Vygotsky and J Piaget's theories on learning shows that both theories can underlie the development of learning in regular classes where there are students with learning disabilities using cooperative learning principles or concepts. The view is the rationale that cooperative learning is an impelmentation of the principle of inclusive education for all children, one of them for children with learning difficulties. In addition, the assumptions underlying the development of learning strategy formulation are as follows:

- Learners as individuals have differences in abilities, barriers and learning needs. These differences need to be accommodated and developed in learning.

- Differences of learners' learning abilities and needs that are diverse can be helped and developed in cooperative group learning. 


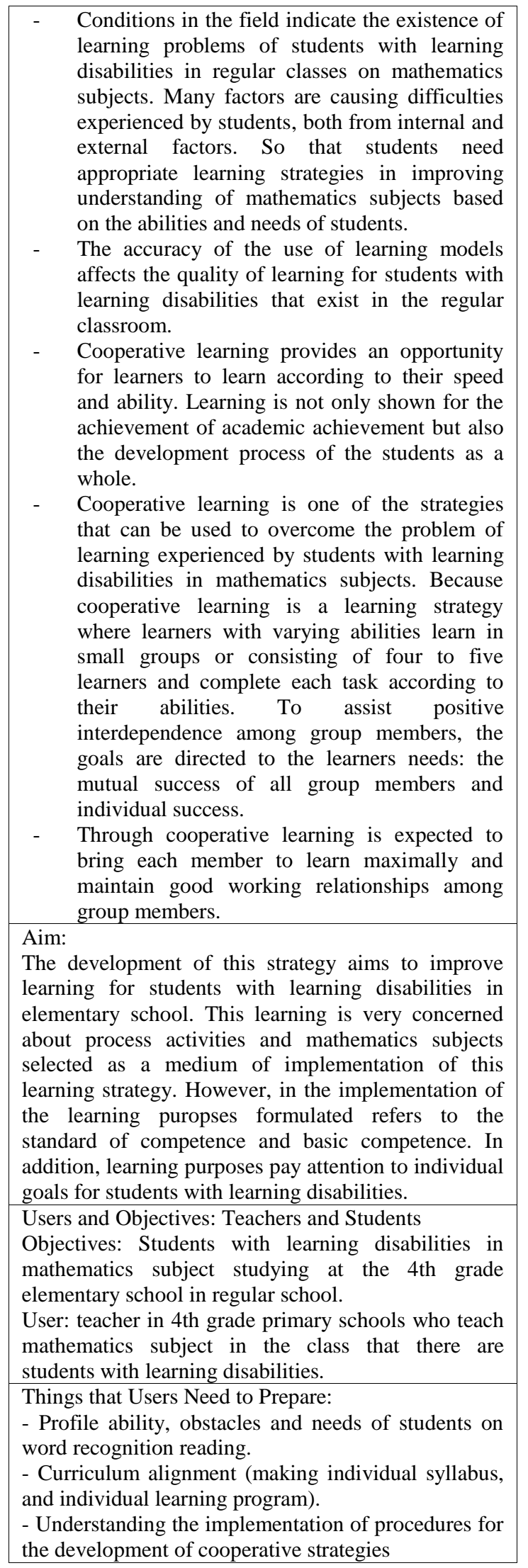

\section{Adaptation of Learning}

In the implementation of cooperative learning is possible there is total communication as an adaptation of learning in implementing cooperative learning. Because if there are students who experience obstacles in communication this strategy can still be applied.

\section{Learning Planning}

Learning planning includes some activities: assessment, setting goals, materials, methods, media, approach, strategies, determining the number of groups, creating groups, seating for each group and designing the implementation of academic evaluation and group behavior.

Learning Materials

The scope of mathematics learning materials for students with learning disabilities in grade 4 is adjusted to the students' learning needs based on the assessment results. The material to be taught includes about knowing numbers (mentioning the number of objects, reading and writing numeric numbers), determining the value of places of numbers to tens and hundreds, writing numbers in length, comparing two numbers, summing and subtraction (results up to 500), and operating a mixed count.

\begin{tabular}{|c|c|c|}
\hline \multicolumn{3}{|c|}{ Procedure of Use } \\
\hline \multirow{2}{*}{$\begin{array}{l}\text { Acti } \\
\text { vities }\end{array}$} & \multicolumn{2}{|c|}{ Activities } \\
\hline & Teachers & Students \\
\hline $\begin{array}{l}\text { Early } \\
\text { Acti } \\
\text { vities }\end{array}$ & $\begin{array}{ll}- & \text { Conditioning } \\
\text { students } \\
\text { - } & \text { Communicating } \\
\text { learning objectives } \\
\text { and learning } \\
\text { outcomes expected } \\
\text { from students } \\
\text { - } \quad \begin{array}{l}\text { Informing the way } \\
\text { of learning to be } \\
\text { done }\end{array} \\
\text { - } \begin{array}{l}\text { Delivering } \\
\text { apperception } \\
\text { Grouping students } \\
\text { based on their } \\
\text { abilities }\end{array} \\
\end{array}$ & 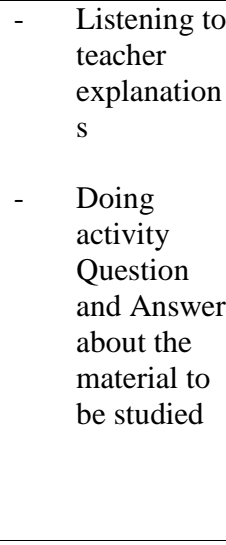 \\
\hline $\begin{array}{l}\text { Main } \\
\text { activ } \\
\text { ities }\end{array}$ & 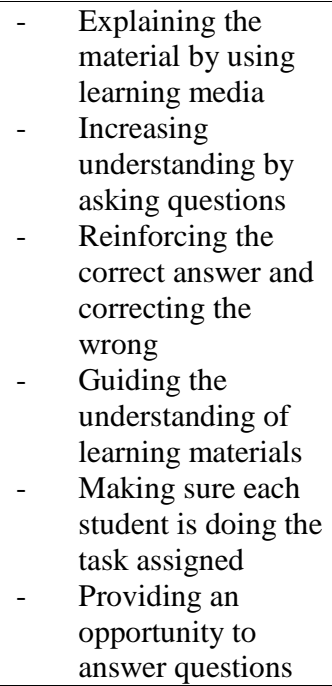 & 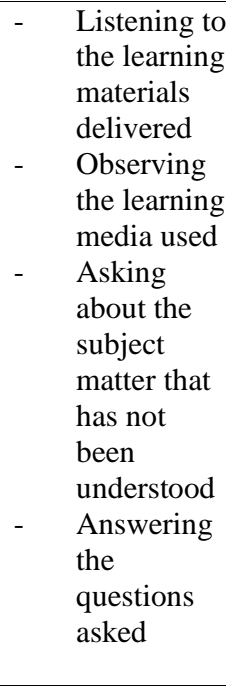 \\
\hline
\end{tabular}




\begin{tabular}{|c|c|c|}
\hline $\begin{array}{l}\text { Grou } \\
\mathrm{p} \\
\text { activ } \\
\text { ities }\end{array}$ & 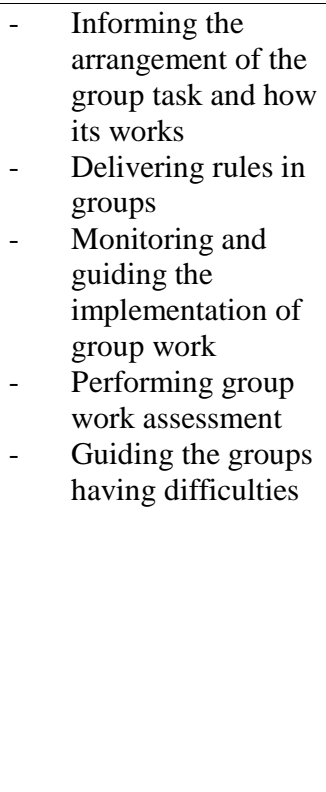 & 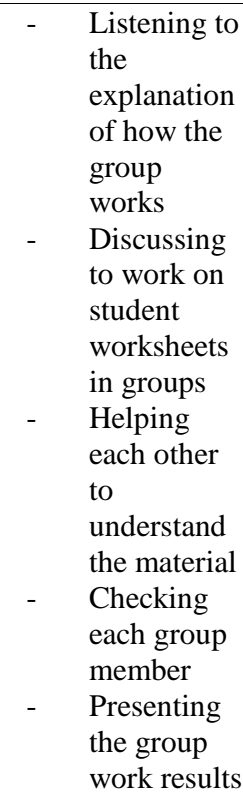 \\
\hline $\begin{array}{l}\text { Indiv } \\
\text { idual } \\
\text { activ } \\
\text { ities }\end{array}$ & $\begin{array}{ll}\text { - } & \text { Giving an } \\
\text { individual test } \\
\text { - } \\
\text { Overseeing the } \\
\text { implementation of } \\
\text { individual tests } \\
\text { - } \begin{array}{l}\text { Discusing the tests } \\
\text { together }\end{array}\end{array}$ & 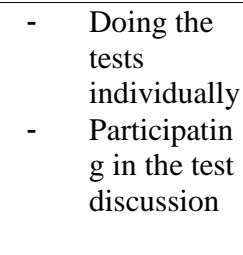 \\
\hline $\begin{array}{c}\text { Calc } \\
\text { ulati } \\
\text { on of } \\
\text { test } \\
\text { score } \\
\text { s and } \\
\text { awar } \\
\text { ds }\end{array}$ & 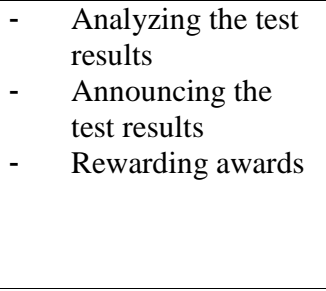 & $\begin{array}{ll}\text { - } & \text { Calculating } \\
\text { the test } \\
\text { results } \\
\text { - } \\
\text { Receiving } \\
\text { test results } \\
\text { - } \\
\text { Receiving } \\
\text { awards to } \\
\text { groups }\end{array}$ \\
\hline $\begin{array}{l}\text { Closi } \\
\text { ng } \\
\text { activ } \\
\text { ities }\end{array}$ & $\begin{array}{l}\text { Doing reflection } \\
\text { activities to reveal } \\
\text { the learning } \\
\text { experiences that } \\
\text { students have } \\
\text { experienced } \\
\text { - } \quad \text { Following up } \\
\text { - } \quad \text { Summarizing the } \\
\text { material and } \\
\text { closing the } \\
\text { learning }\end{array}$ & $\begin{array}{l}\text { Revealing } \\
\text { experiences } \\
\text { about group } \\
\text { activities } \\
\text { that have } \\
\text { just been } \\
\text { done } \\
\text { Listening to } \\
\text { the follow- } \\
\text { up given }\end{array}$ \\
\hline $\begin{array}{c}\text { Eval } \\
\text { uatio } \\
n\end{array}$ & \multicolumn{2}{|c|}{$\begin{array}{l}\text { Evaluation towards learning results includes } \\
\text { a process to assess social skills and academic } \\
\text { ability. }\end{array}$} \\
\hline $\begin{array}{l}\text { Strat } \\
\text { egy } \\
\text { Supp } \\
\text { ortin } \\
\text { g } \\
\text { Com } \\
\text { pone } \\
\text { nts }\end{array}$ & \multicolumn{2}{|c|}{$\begin{array}{l}\text { Supporting components to support the } \\
\text { implementation of this Strategy consist of: } \\
\text { a. Screening Procedure for } \\
\text { Cooperative Groups } \\
\text { b. Cooperative Group Rating Table }\end{array}$} \\
\hline
\end{tabular}

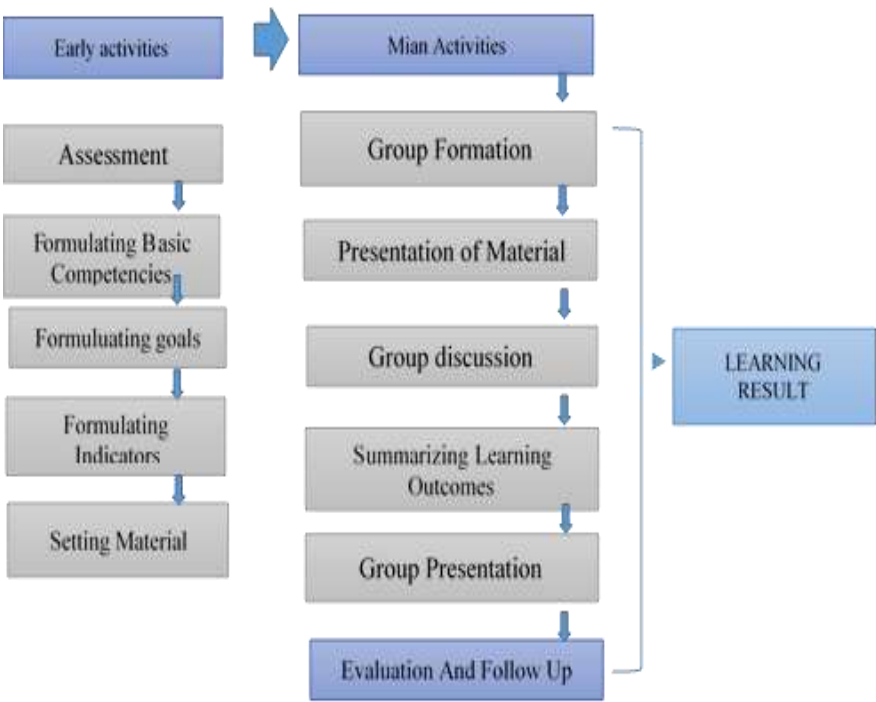

Fig. 1. The scheme and steps for developing the cooperative learning strategy

\section{Test of The Implementation of Learning Strategy}

Implementation of learning in the implementation test shows that this learning is applied as a planned learning plan that has been designed. Although there are several stages of learning that still needs to be refined. But for the test of implementation in the implementation of cooperative learning strategies for students with learning disabilities is enough to provide input to the design of lesson plans, implementation and evaluation of learning. This learning activity shows there is an increase in learning and social skills (empathy, motivation and cooperation) among students with learning disabilities and students who are not learning disabilities.

Based on the findings and studies on the implementation of this test, it is concluded some notes as input for the implementation of learning on a wider scale. The notes are as follows:

1. To improve the effectiveness of learning strategies in the implementation test, it needs to further improve the learning conditions that are more optimal in accordance with the principles of learning developed. The implication is that teachers should create learning that provides opportunities and stimuli to students to interact and cooperate in learning situations between students with learning disabilities and no learning disabilities.

2. In the grouping process, students should be advised to group with several groups in rotation. It is intended that all students gain learning experience from other students. In addition, students without learning disabilities get an understanding of the differences, so it is expected to arise a sense of tolerance and respect for diversity.

3. This cooperative learning strategy can be used in all subjects such as mathematics, social sciences, natural sciences and other subjects, based on adaptive and comprehensive learning principles. 


\section{CONCLUSION}

The development of the draft strategy is intended to produce a learning strategy to improve the academic ability and social skills of students with learning disabilities in primary school.

Theoretically this cooperative learning strategy is based on the basic principles of cooperative learning. Those are 1) Positive Interdependence, 2) Individual Accountability, 3) Equal Participation, 4) Simultaneous Interaction ( Simultaneous Participation) 5) Adaptive and inclusive, both in formulating student goals, indicators, materials, evaluation and grouping systems, 6) Group awards.

Component strategy consists of planning, implementation and evaluation as a basic component in which there is a substance cooperative learning strategy. So, through cooperative learning, all students can accommodate their learning needs.

Implementation of cooperative learning strategy consists of cooperative learning principles, learning scenarios, and evaluation system. The procedures for implementing cooperative learning strategies in general are group formation, material presentations, learning in groups, quiz/test assignments, awards giving, and follow up in each learning. In the learning process, the development of this learning strategy applies adjustments based on the needs and development of students. Adjustments will be seen for students with learning disabilities, especially on objective, material and evaluation components. This learning provides opportunities for teaching and learning process among students who have more ability to help students with learning disabilities. This strategy is believed to increase confidence and acceptance among peers.

\section{REFERENCES}

[1] Abdurrahman. M, "Pendidikan bagi anak berkesulitan belajar", Jakarta: Rineka Cipta, 2009.
[2] Abdurrahman. M, Pendidikan bagi anak berkesulitan belajar", Jakarta: Rineka Cipta, 2010.

[3] Antil. L.R, Jenkins. J.R. Wayne S.K. \& Vadasy. P.F, "Cooperative Learning: Prevalence, Conceptualization, and the relation between research and practice", American Educational Research Journal, 35, pp 419-454, 1998,

[4] Geary. D. C, "Mathematics and learning disabilities", Journal of learning disabilities, 37(1), 4-15, 2004.

[5] Gersten. R., Jordan,N. C., \& Flojo, J. R, "Early identification and intervention for students with mathematics difficulties", Journal of Learning Disabilities, 38(4), pp. 293-304, 2005.

[6] Gilles. R.M, \& Adrian, F.A, "The Effects Of cooperative learning on students with learning disabilities in lower elementary school", The journal of special educaton vol.34 (1), pp.. 19-27, 2000.

[7] Goor. M.B, \& Schween. J.O, "Acomodating diversity and disability with cooperative learning", Intervention in school and clinic 29, pp 616, 1993.

[8] Johnson. R.T, \& Johnson. R.T, "Implementing cooperative learning", Temporary Education 63, pp. 173-180, 1992.

[9] Margolis. H, \& Freund L.A, "Implementing cooperative learning with mildly handicapped students in regular classroom", International journal of disability: develompment and education, 38, pp. 117-133, 1991.

[10] Masroza. F, "Prevalensi anak berkesulitan belajar di sekolah dasar sekecamatan Pauh Padang", Jurnal Ilmiah Pendidikan Khusus, Vol.1, No.1, pp. 215-227, 2013.

[11] Mastropieri. M.A \& Scruggs, "What's special about special education? A cautious view toward full inclusion", Educational Forum, 61. pp.206-211, 1997.

[12] Murphy. E, Lan. M.G \& Rita Honan, "Cooperative learning for student with difficulties in learning: a description of models and guidlines for implementation”, British Journal of Special Education-volume 32, No. 3 pp. 157-164, 2005.

[13] Rudiyati. S., Pujaningsih, \& Ambarwati, U, "Penanganan anak berkesulitan belajar berbasis akomodasi pembelajaran", Jurnal Kependidikan, Vol. 40, No. 2, 187-200, 2010.

[14] Sanjaya. W, "Strategi pembelajaran berorientasi standar proses pendidikan", Jakarta: Prenadamedia Group, 2006.

[15] Slavin, E Robert, "Pengantar Psikologi". I ( $8^{\text {nd }}$ ed $)$. Alih Bahasa. Allyma Bacon, 2006.

[16] Yusuf. M, "Pendidikan Bagi anak dengan problema Belajar", Yogyakarta: $\quad$ Tigaserangkai, 2003. 